Restraints on publication

\title{
Deal in prospect on US export rules
}

Washington

A WORKING group headed by the President's Office of Science and Technology Policy has recommended that draft export control regulations be altered to provide greater freedom for scientific communications. This was announced by Charles Herz, general counsel of the National Science Foundation and a member of the group, speaking at a meeting of the Department of DefenseUniversity Forum last week. The forum had made several specific suggestions to the Department of Commerce, the agency charged with writing the regulations, chief among them being the idea that fundamental research should be controlled only through national security classification and not through any rules requiring universities to obtain an export licence before publishing research results.

The group also recommended that when export controls are applied to university research, research contracts - rather than licensing procedures - should be the enforcement mechanism. The point is an important one to universities, which have demanded to know in advance of accepting research contracts whether their freedom to publish will be restricted. Many universities as a matter of policy refuse to accept such restrictions.

Under the working group's proposed changes, any research at universities that complies with contract terms would automatically be granted a "general licence" for "export" - a term which includes publication. The situation now is that universities in principle could find themselves in double jeopardy in that publication may be cleared by the Department of Defense (DOD), but still be held a violation of export rules by the Department of Commerce.

An earlier plan to establish a broad category of "sensitive" but unclassified research that could be subject to export controls was abandoned by DOD in May in the face of stiff university opposition. DOD's revised policy exempts "fundamental" research from controls.

But questions remain over just how DOD and the other federal agencies plan to apply export controls to publication other than fundamental research. David Wilson, the universities' co-chairman of the DODUniversity Forum committee on export controls, recommended that export controls incorporated in research contracts should permit DOD only a 60 -day review before publication. DOD could then advise the university of information in the proposed publication that would violate the export act if published, but the ultimate

decision whether or not to publish would remain with the university.

The definition of "fundamental" research remains unclear. DOD officials and Wilson seem to agree that a reasonable approach would be to define as fundamental on-campus research in what DOD calls categories 6.1 or 6.2 , which correspond to basic research and "advanced technology development" respectively. More than 99 per cent of oncampus research supported by DOD is said to fall in these two categories, while the remainder is in category 6.3 , "strategic programmes". That, as well as 6.2 research conducted at off-campus facilities such as Johns Hopkins University's Applied Physics Laboratory, could be subject to contract restrictions based on export control authority. (An exception is to be

\section{AIDS \\ Virus clones multiply}

Washington

YET another US genetic engineering company has jumped on the bandwagon of acquired immune deficiency syndrome (AIDS). The Chiron Corporation, of Emeryville, California, announced last week that its researchers had succeeded in cloning the entire genome of a putative AIDS virus isolated by Dr Jay Levy of the University of California at San Francisco. Earlier this year, Chiron was not among those companies selected by the federal government to develop a diagnostic blood test for AIDS from virus isolated at the National Institutes of Health by Dr Robert Gallo.

Following the frequent practice of some genetic engineering companies, Chiron made its announcement without at the same time publishing details of its accomplishment. Lacey Overby, a vice-president of Chiron, said that a scientific manuscript describing the process was essentially complete and ready to be submitted for publication. Overby averred that scientific journals seemed not to mind publishing previously announced findings. Chiron plans to work on expressing the viral proteins in yeast cells, a field in which it already has expertise.

Chiron says it assumes that the virus isolate it is using is the same as the human T-cell leukaemia virus III isolated by Gallo. The cloning of the virus paves the way for a widely available diagnostic test that does not require the intact virus to be used, as well as, perhaps, a vaccine.

But Chiron is not alone in the race to produce an AIDS diagnostic nor the first to made for star wars research which, although categorized as 6.3 , will for the most part be considered fundamental.)

DOD officials say they need the "flexibility" to apply restrictions to sensitive research that does not warrant classification, which they say is "a pain in the neck", because classified documents are subject to security restrictions - they must be kept in locked cabinets, for example, and cannot leave of fices or be left lying on desks. Stephen Budiansky - Meanwhile, a revised Export Administration Act - needed to implement the regulations - remains stalled in Congress. At a conference committee meeting last week, House members refused to accept compromises offered by the Senate on contract sanctity and national security. More meetings are planned this week. The commerce department, however, has shifted its position on high-technology exports of equipment (as opposed to information). Its latest proposals would allow the exporting companies themselves to enforce the regulations, subject to audit by the departments. have cloned an AIDS-linked virus. Gallo has also now cloned his viral isolate, and probably others have done the same without making an announcement.

Chiron says its public statement is justified by the "intense competition" in the field. Chiron expects to be making a profit within the next 18 months (it was incorporated only in 1981) and reports that clinical trials on what is likely to be its first commercially available product, a genetically engineered hepatitis $B$ vaccine, are going well.

Tim Beardsley

\section{Entrance standards}

\section{on increase}

BRrTISH universities are demanding higher examination grades from prospective students than they did in 1980. This conclusion can be drawn from Universities Central Council on Admissions (UCCA) statistics recently released. Entrance requirements for each of the 24 main university subjects have risen with those for electrical engineering and computer sciences showing the most marked rise.

UCCA believes that the increasingly high standards required for university entrance are deterring marginal candidates - those who may not have attended good secondary schools but might, nevertheless thrive at university - from applying. The statistics also show that young people from wealthier families are still over-represented among successful applicants.

Marcus Chown 